\title{
Rapid Monitoring of Escherichia coli in Southeast Asian Urban Canals by Fluorescent- Bacteriophage Assay
}

\author{
Takehiko Kenzaka, ${ }^{a, b}$ Fuangfa Utrarachkij, ${ }^{c}$ Orasa Suthienkul, ${ }^{c}$ and Masao Nasu*, ${ }^{*}$ \\ ${ }^{a}$ Faculty of Environment and Resource Studies, Mahidol University, 4, Phuttamonthon, Salaya, Nakorn Pathom, 73170, Thailand, \\ ${ }^{b}$ Graduate School of Pharmaceutical Sciences, Osaka University, 1-6, Yamada-oka, Suita, Osaka 565-0871, Japan, and ${ }^{c}$ Faculty of \\ Public Health, Mahidol University, 420/1, Rajvithi Rd., Bangkok, 10400, Thailand
}

(Received May 8, 2006; Accepted August 12, 2006)

\begin{abstract}
The microbial water quality in canals of metropolitan Bangkok, Thailand, was assessed using the fluorescent bacteriophage assay (FBA) and fluorescence in situ hybridization (FISH). When FISH was used with oligonucleotide probes targeted to Escherichia coli (E. coli) and anaerobic Bacteroides group, $<0.1 \%$ to $7 \%$ and $<0.1 \%$ to $11 \%$, respectively, of the total bacteria were identified. Estimates of viable $E$. coli determined by FBA with $4^{\prime}, 6-$ diamidino-2-phenylindole (DAPI)-labeled T4 bacteriophage, which accounted for 1 to $8 \%$ of total cells, were significantly higher than those of fecal coliforms determined by the most probable number method. The FBA procedure can specifically detect viable $E$. coli in canal water samples that are grossly contaminated with fecal flora within 30 min, and it can quickly deliver accurate findings for risk assessment of environmental contamination in water samples.
\end{abstract}

Key words — canal, fluorescence in situ hybridization, fluorescent bacteriophage assay, fecal bacteria

\section{INTRODUCTION}

Contamination of municipal water with pathogenic microorganisms constitutes a serious threat to public health. The coliform count obtained using the most probable number (MPN) method is the most frequently applied indicator of recent fecal contamination in freshwater. However, at least $24 \mathrm{hr}$ are required to generate results and the applicability to natural habitats is limited by low sensitivity, because many environmental bacteria resist proliferation in laboratory media. ${ }^{1)}$ Thus, rapid and sensitive methods are required to detect and enumerate fecal bacteria in natural waters.

Fluorescence in situ hybridization (FISH) with rRNA-targeted oligonucleotide probes can provide information about the absolute abundance and size of bacterial cells with defined phylogenetic affiliations. ${ }^{1-3)}$ Despite some limitations, this method has potential to identify and cytometrically analyze microbes. The FISH procedure can generate results in just over $3 \mathrm{hr}$.

*To whom correspondence should be addressed: Graduate School of Pharmaceutical Sciences, Osaka University, 1-6, Yamada-oka, Suita, Osaka 565-0871, Japan. Tel.: +81-6-68798170; Fax: +81-6-6879-8174; E-mail: nasu@phs.osaka-u.ac.jp
Fluorescent-bacteriophage assays (FBA) can identify and enumerate specific strains of bacteria and cyanobacteria in mixed microbial assemblages, ${ }^{4)}$ and determine the rates of production and removal of marine viruses. ${ }^{5)}$ Bacteriophages specific for some strains of Escherichia coli (E. coli) have been isolated, ${ }^{6}$ and FBA has detected E. coli $\mathrm{O} 157: \mathrm{H} 7$ in inoculated ground beef and in raw milk. ${ }^{7,8)}$ This technique requires less than $30 \mathrm{~min}$ when sample enrichment is not required.

Here, we performed fluorescence-based rapid detection of $E$. coli in aquatic samples using FBA and FISH with rRNA-targeted probes to assess microbial water quality in canals of metropolitan Bangkok, Thailand.

\section{MATERIALS AND METHODS}

Sampling Sites — Water samples were collected at 4 sites (L1, L2, L3, L4) in the Lord Canal, 2 (CP2, CP2-1) in the Chao Phraya River (Fig. 1A), and 10 in canals of metropolitan Bangkok from August 2000 to March 2001 (Fig. 1B). Figure 1C shows a wide area map of the sampling sites in Central Thailand. The Lord Canal originates in the Chao Phraya River at Phra Pin Klao Bridge, and initially flows under a 
A

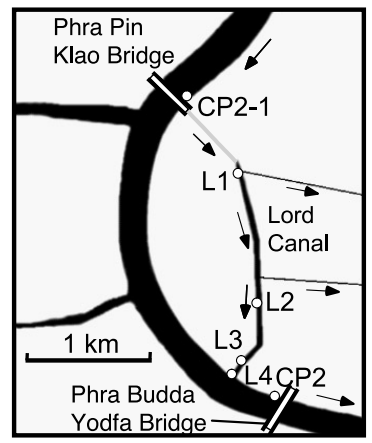

B

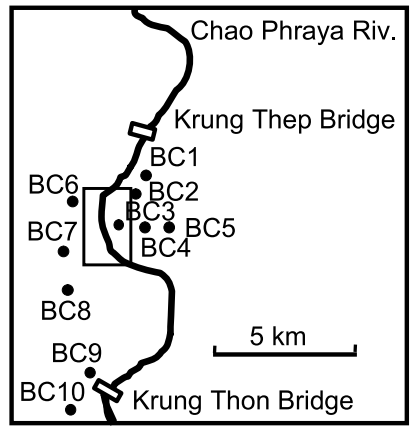

$\mathrm{C}$

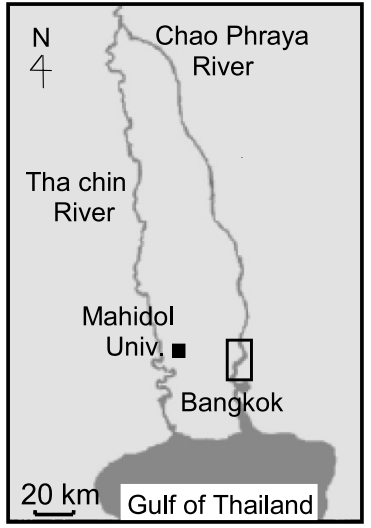

Fig. 1. Sampling Sites in Canals and River of Metropolitan Bangkok

(A) Sampling sites around the Lord Canal. Arrows show direction of stream. Gray line represents underground stream. Map A represents magnified view of middle of map B. (B) Sampling sites in 10 canals. Map B represents magnified view of middle area in map C. (C) Map of coastal area of Thailand.

road (Fig. 1A). It appears above ground at L1, and flows for about $1.5 \mathrm{~km}$ before rejoining the Chao Phraya River about $400 \mathrm{~m}$ up from the Phra Budda Yodfa Bridge. Domestic water flows directly into the Lord Canal, where some residents fish and wash clothes. Arrows show the direction of the stream and the gray line represents the underground stream.

Other sampling sites in canals were named as follows (parentheses contain name, width and depth of canal, respectively): BC1 (Phadung Krung Kasem, $22 \mathrm{~m}, 2.5 \mathrm{~m}$ ), BC2 (Bang Lamphoo, $23 \mathrm{~m}, 1.3 \mathrm{~m}$ ), BC3 (Lord, $12 \mathrm{~m}, 0.8 \mathrm{~m}$ ), BC4 (Wat Thepthida, $5 \mathrm{~m}$, $0.6 \mathrm{~m}$ ), BC5 (Mahanak, $18 \mathrm{~m}, 2 \mathrm{~m}$ ), BC6 (Bangkok Noi, $54 \mathrm{~m}, 7 \mathrm{~m}$ ), BC7 (Mon, $16 \mathrm{~m}, 3 \mathrm{~m}$ ), BC8 (Bangkok Yai, 40 m, 4 m), BC9 (Bang Nam Chon, $9 \mathrm{~m}, 1 \mathrm{~m}$ ), BC10 (Dao Khanong, $42 \mathrm{~m}, 4 \mathrm{~m}$ ) (Fig. 1B). All samples were taken from residential and commercial areas. Some canals are wide enough for boat running, and play important roles in daily transport and tourism. Some sewage plants have been constructed in Bangkok, but the total number remains insufficient, and drainpipe connections are sometimes incomplete. Domestic water also flows directly into some canals. Water $(100 \mathrm{ml})$ sampled from the surface at each site was transported to the laboratory on ice.

\section{Total Direct Counting and Quantitative Direct} Counting — Total direct counts (TDC) in the river and canal water samples were determined using $4^{\prime}, 6^{\prime}$ diamidino-2-phenylindole (DAPI) at a final concentration of $1 \mu \mathrm{g} \mathrm{ml}^{-1}$. Viable bacteria in the water samples were determined by quantitative direct viable counting as described by Yokomaku et al. (quantitative direct viable counts, qDVC). ${ }^{9}{ }^{9}$ This method is based on the selective lysis of viable cells by spheroplast formation after incubating samples with antibiotics, nutrients (yeast extract) and glycine. Antibiotics specifically inhibit DNA synthesis and prevent cell division without affecting other cellular metabolic activities. Glycine induces spheroplast formation by viable cells because glycine interferes with several steps in peptidoglycan synthesis for bacterial cell wall formation. This effect leads to swollen cells with very loose cell walls. The viable cells are lysed by freeze-thaw treatment following spheroplast formation.

Plate Counting and Fecal Coliform — The number of colony forming units (CFU) was determined by spreading dilute river water samples on R2A medium, ${ }^{10)}$ which were incubated at $30^{\circ} \mathrm{C}$ for 1 week before counting. The mean and standard deviations were calculated from triplicate samples. Fecal coliforms were determined using the MPN method with EC broth. ${ }^{11}$

Fluorescent-Bacteriophage Assay — The T4 phage labeled with DAPI was obtained from Organo Co. (Toda, Japan) and from Fuji Electric Co. (Yokosuka, Japan). Modified Sholten's broth ${ }^{12)}$ was inoculated with the samples at a final concentration of $10 \%(\mathrm{v} / \mathrm{v})$, and incubated at $30^{\circ} \mathrm{C}$ for $30 \mathrm{~min}$. Fluorescent-bacteriophage suspension (1/16 volume of each sample) was added and the samples were incubated at $30^{\circ} \mathrm{C}$ for $20 \mathrm{~min}$. Ethidium bromide (EtBr; $2 \mathrm{mg} \mathrm{ml}^{-1}$ in sterilized water; Sigma) and 9\% (w/v) paraformaldehyde in phosphate-buffered saline (PBS; $137 \mathrm{mM} \mathrm{NaCl}, 2.7 \mathrm{mM} \mathrm{KCl}, 8.1 \mathrm{mM} \mathrm{Na}_{2} \mathrm{PO}_{4}$, $1.5 \mathrm{mM} \mathrm{KH}_{2} \mathrm{PO}_{4}, \mathrm{pH} 7.2$ ) were added to the samples at a final concentration of $120 \mu \mathrm{g} \mathrm{ml}^{-1}$ and $3 \%(\mathrm{w} /$ 
v), respectively. After a 10 min incubation, stained bacteria were trapped onto a black polycarbonate membrane (diameter, $25 \mathrm{~mm}$; pore size, $0.2 \mu \mathrm{m}$; ADVANTEC, Tokyo, Japan).

Oligonucleotide Probes — The following rRNAtargeting oligonucleotide probes were used for FISH: (i) EUB338 (5'-GCTGCCTCCCGTAGGAGT-3'), which is complementary to a conserved region of most bacterial 16S rRNA molecules; ${ }^{13)}$ (ii) BAC303 ( $5^{\prime}$-CCAATGTGGGGGACCTT- $\left.3^{\prime}\right)$, which is complementary to a signature region of the $16 \mathrm{~S}$ rRNA of Bacteroides cluster of CFB-phylum; ${ }^{14)}$ (iii) ES445 (5'-CTTTACTCCCTTCCTCCC-3'), which is complementary to a signature region of the 16S rRNA of E. coli; ${ }^{15)}$ (iv) NON338 (5'ACTCCTACGGGAGGCAGC-3'), which is negative control probe. ${ }^{16)}$ All oligonucleotide probes were fluorescently labeled with CY3.

\section{Fluorescence in situ Hybridization — FISH was} carried out as described by Kenzaka et al. (2001). ${ }^{15)}$ $12 \%(\mathrm{w} / \mathrm{v})$ paraformaldehyde in PBS was added to the collected samples in a final concentration of $3 \%$ $(\mathrm{w} / \mathrm{v})$ and cells were fixed at $4{ }^{\circ} \mathrm{C}$ overnight. Cells were concentrated from water samples $(0.5$ to $1.0 \mathrm{ml})$ on black polycarbonate filters (diameter, $25 \mathrm{~mm}$; pore size, $0.2 \mu \mathrm{m}$; ADVANTEC). Hybridization solution consisted of $0.9 \mathrm{M} \mathrm{NaCl}(0.45 \mathrm{M}$ for probe ES445), $20 \mathrm{mM}$ Tris- $\mathrm{HCl}$ (pH 7.5), $0.1 \%$ sodium dodecyl sulfate and $50 \mathrm{ng}$ of CY3-labeled oligonucleotide, and each filter section was incubated at $46^{\circ} \mathrm{C}\left(41^{\circ} \mathrm{C}\right.$ for probe ES445) for $3 \mathrm{hr}$. The filter section was incubated in washing solution $[0.9 \mathrm{M}$ $\mathrm{NaCl}$ (80 mM for probe ES445), $20 \mathrm{mM}$ Tris- $\mathrm{HCl}$
(pH 7.5), $0.1 \%$ sodium dodecyl sulfate] at $48^{\circ} \mathrm{C}$ $\left(41^{\circ} \mathrm{C}\right.$ for ES445 probe) for $15 \mathrm{~min}$. Counterstaining was carried out with DAPI solution $\left(2 \mu \mathrm{g} \mathrm{ml}^{-1}\right.$ in sterilized water).

Microscopy — The filter sections were observed with ECLIPSE E400 epifluorescence microscope (Nikon, Tokyo, Japan) equipped with a 100-W mercury burner and specific filter sets (UV-2A for DAPI; HQ:CY3 for CY3; B-2A for EtBr). For the DAPI examination, more than 1500 cells were counted per sample. All probe-specific cell counts are presented as the percentage of cells visualized by DAPI. The mean abundances and standard deviations were calculated from the counts of 10 to 20 randomly chosen microscopic fields on each filter section. For FISH, all counts were corrected by subtracting the counts obtained with the negative control NON338. For FBA, all counts were corrected by subtracting the counts of particles with autofluorescence. All results were shown as representative data. The mean abundances and standard deviations were calculated from the counts of 10 to 20 randomly chosen fields on each filter section.

\section{RESULTS}

Figure 2 shows the number of bacteria in the Lord Canal and Chao Phraya River. Total cell counts increased in water flowing from the Chao Phraya River to the Lord Canal, and the value was the highest at L3. However, the value decreased approximately by one order of magnitude after the canal
A

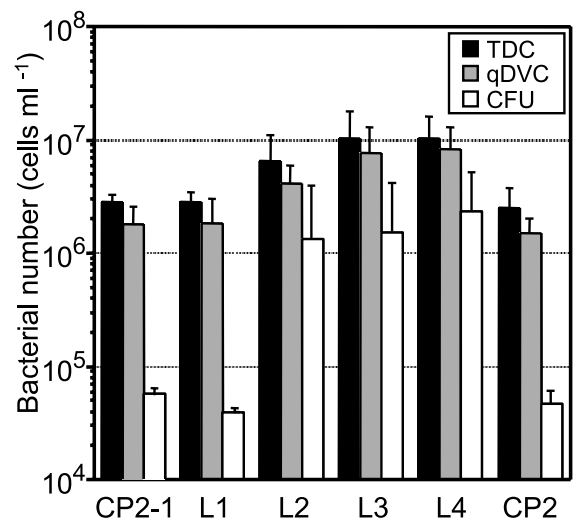

B

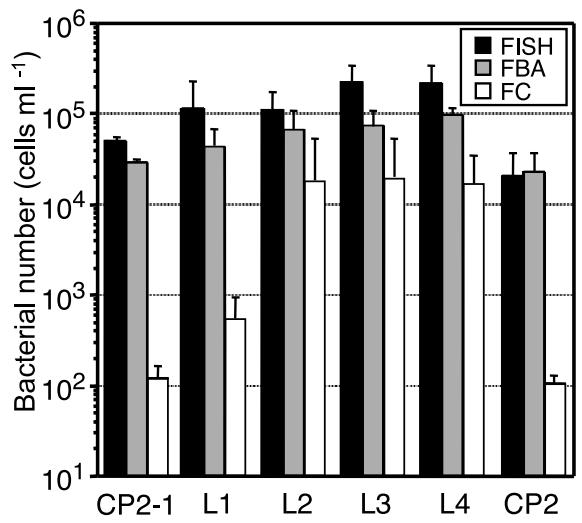

Fig. 2. Abundance of Heterotrophic Bacteria (A) and E. coli (B) in Bangkok Canals and One River

(A) TDC, total direct counts (determined with DAPI); qDVC, viable cell counts (determined with quantitative direct viable counting); CFU, colony forming units (determined with R2A medium). (B) FISH, E. coli cell counts (determined by direct viable counting-fluorescence in situ hybridization); FBA, viable $E$. coli cell counts (determined with fluorescent bacteriophage assay); FC, fecal coliforms (determined with EC broth). Error bars indicate standard deviation $(n=4)$. 
Table 1. Abundance of Fecal Bacteria in Canals of Metropolitan Bangkok

\begin{tabular}{|c|c|c|c|c|c|c|c|c|}
\hline Sites & $\begin{array}{l}\text { TDC } \\
10^{6} \mathrm{ml}^{-1}\end{array}$ & & $\mathrm{FU}$ & $\begin{array}{l}\text { FISH } \\
\%^{e)}\end{array}$ & $\begin{array}{l}\text { Fecal coliform } \\
\\
10^{3} \mathrm{ml}^{-1}(\%)^{e)}\end{array}$ & $\begin{array}{c}\mathrm{FBA}^{b)} \\
10^{3} \mathrm{ml}^{-1}(\%)^{e)}\end{array}$ & $\begin{array}{c}\mathrm{ES} 445^{c)} \\
10^{3} \mathrm{ml}^{-1}(\%)^{e)}\end{array}$ & $\begin{array}{c}\text { BAC303 }^{d)} \\
10^{3} \mathrm{ml}^{-1}(\%)^{e)}\end{array}$ \\
\hline $\mathrm{BC} 1$ & 4.4 & 32 & \pm 14 & $38 \pm 7.8$ & $1.3(0.029)$ & $47 \pm 54(1.1 \pm 1.2)$ & $<4.4(<0.1)$ & $28 \pm 39(0.6 \pm 0.9)$ \\
\hline $\mathrm{BC} 2$ & 4.6 & 28 & \pm 16 & $26 \pm 12$ & $1.3(0.028)$ & $39 \pm 48(0.8 \pm 1.0)$ & $29 \pm 38(0.6 \pm 0.8)$ & $4.6(<0.1)$ \\
\hline $\mathrm{BC} 3$ & 10 & 72 & \pm 14 & $76 \pm 16$ & $13(0.13)$ & $90 \pm 54(0.9 \pm 0.5)$ & $410 \pm 220(4.1 \pm 2.2)$ & $1110 \pm 260(11 \pm 2.6)$ \\
\hline $\mathrm{BC} 4$ & 12 & 76 & \pm 2.9 & $69 \pm 11$ & $24(0.19)$ & $150 \pm 71(1.2 \pm 0.6)$ & $700 \pm 300(5.9 \pm 2.5)$ & $930 \pm 390(7.8 \pm 3.2)$ \\
\hline BC5 & 8.7 & 22 & \pm 1.2 & $83 \pm 7.0$ & $54(0.62)$ & $450 \pm 280(5.1 \pm 3.2)$ & $540 \pm 220(6.2 \pm 2.5)$ & $190 \pm 150(2.1 \pm 1.7)$ \\
\hline BC6 & 5.0 & & \pm 1.3 & $11 \pm 6.3$ & $0.13(0.0026)$ & $380 \pm 150(7.6 \pm 2.9)$ & $176 \pm 200(3.5 \pm 4.0)$ & $176 \pm 110(3.5 \pm 2.2)$ \\
\hline BC7 & 5.8 & 16 & \pm 4.7 & $10 \pm 3.7$ & $0.23(0.0040)$ & $90 \pm 48(1.5 \pm 0.8)$ & $52 \pm 57(0.9 \pm 1.0)$ & $33 \pm 35(0.6 \pm 0.6)$ \\
\hline BC8 & 5.5 & 20 & \pm 5.5 & $22 \pm 9.6$ & $0.22(0.0040)$ & $89 \pm 40(1.6 \pm 0.7)$ & $140 \pm 146(2.5 \pm 2.7)$ & $180 \pm 90(3.2 \pm 1.6)$ \\
\hline BC9 & 13 & 54 & \pm 14 & $64 \pm 15$ & $2.4(0.019)$ & $150 \pm 86(1.1 \pm 0.7)$ & $860 \pm 300(6.6 \pm 2.3)$ & $480 \pm 240(3.7 \pm 1.9)$ \\
\hline $\mathrm{BC} 10$ & 2.2 & 52 & \pm 3.1 & $27 \pm 10$ & $0.33(0.015)$ & $70 \pm 30(3.2 \pm 1.4)$ & $140 \pm 71(6.1 \pm 3.2)$ & $140 \pm 71(6.1 \pm 3.2)$ \\
\hline
\end{tabular}

a) Fecal coliform determined by MPN method. b) Viable E. coli determined by FBA. c) E. coli determined by FISH. $d$ ) Bacteroides group determined by FISH. e) $\%$ of total count.

joins the river. This was also true of viable cells determined by direct counting. The change in the numbers of colony forming units in water flowing between the river and canal was more appreciable.

The applicability of FBA was examined using the same water samples. Figure $2 B$ shows the number of E. coli in the Lord Canal and Chao Phraya River. Escherichia group counts and viable E. coli cell counts increased in water flowing from the Chao Phraya River to the Lord Canal, and the value peaked at $\mathrm{L} 3$. This value also decreases after the canal joins the river. Estimates of fecal coliforms determined by the MPN method were 6 to 200 fold-lower than those by the other two methods, and the change in water flowing between the river and canal was more obvious.

The abundance of fecal and viable bacteria in other canals of metropolitan Bangkok was further investigated, and the results are summarized in Table 1. The total cell counts in the canals $\left(2.2 \times 10^{6}\right.$ to $1.3 \times 10^{7}$ cells $\mathrm{ml}^{-1}$ ) were within the range reported for eutrophic river systems. ${ }^{17)}$ Estimates of culturable bacteria in the canals were extremely high, constituting 6.7 to $76 \%$ (average: $38 \%$ ) of the total bacteria. Direct microscopic counts of bacteria from aquatic habitats usually exceed viable plate counts by several orders of magnitude. ${ }^{18,19)}$ Plate counting with R2A media has yielded more colony forming bacteria,${ }^{10)}$ especially in eutrophic river samples. ${ }^{17)}$ Between 10 and $83 \%$ (average: $43 \%$ ) of the total cells was visualized by FISH using the probe EUB338 targeted to the domain Bacteria.

The anaerobic Bacteroides genus is the most common among human intestinal microflora and it outnumbers coliforms..$^{20,21)}$ Thus, abundance of
Bacteroides organisms in canals was also examined using FISH with rRNA-targeted probes for Bacteroides group (Table 1). Estimates of fecal coliforms in samples from $\mathrm{BC} 3, \mathrm{BC} 4$ and $\mathrm{BC} 5$ were much higher than those found in ambient water quality criteria, ${ }^{22)}$ and in situ detection with BAC303 probes revealed that the Bacteroides group accounted for 2 to $11 \%$ of the total bacteria except for $\mathrm{BC} 1, \mathrm{BC} 2$ and $\mathrm{BC} 7$. Estimates of $E$. coli determined by FBA were higher than those of fecal coliforms obtained by MPN, and accounted for 1 to $8 \%$ of the total cells. FISH with ES445 identified $<0.1 \%$ to $7 \%$ of the total bacteria.

\section{DISCUSSION}

The standard indicator of recent fecal contamination under most conditions in temperate freshwater has historically been coliforms. Contamination levels in tropical countries have been monitored using coliforms despite reports that free-living species might be indigenous to some tropical waters. ${ }^{23)}$ The present study used the conventional fecal coliform test as well as culture independent methods, namely in situ identification with rRNA-targeted probes for E. coli and fluorescently labeled T4 phage.

Figure 2 shows an obvious difference in the quantity of fecal bacteria between culture-dependent and -independent methods. The number of culturable E. coli is highly dependent on culture conditions as well as on the components of the media, and natural habitats are difficult to adapt to high nutrient concentrations. ${ }^{10)}$ On the other hand, the FBA procedure is based on direct observation under an epifluorescence microscope and should be more 
rapid and sensitive. A comparison of estimates of $E$. coli determined by FBA and by FISH showed that the numbers of $E$. coli determined by FBA were generally lower than those by in situ hybridization with ES445 except for samples from a few sites (Table 1). Only the most physiologically active viable $E$. coli cells can be determined by FBA. The identification of microorganisms based upon bacteriophage depends on the host range of the bacteriophage. Although the T4-phage is specific for E. coli, some $E$. coli strains are not infected by this phage.

The results shown in Fig. 2 and in Table 1 imply that the physiological state of resident bacteria in the canal differs greatly from habitats in the river. The high abundance of E. coli and physiological activity in the canal are decreased in water flowing into rivers but they do survive in the Chao Phraya River. Several of the canals with a high abundance of E. coli, Bacteroides and high physiological activity are shallow and less than $20 \mathrm{~m}$ wide. A large amount of untreated or incompletely treated domestic waste flows directly into these shallow and narrow canals, and active cells in such sources might cause contamination. Waste water is not diluted in those canals as effectively as in wider canals. Thus, the in situ physiological activity of resident bacteria might generally be high in several canals. In general, physiological activity of resident bacteria in eutrophic environments is high and the difference between numbers of culturable bacteria and nonculturable bacteria in eutrophic environments were smaller than in oligotrophic environments. ${ }^{15,17)}$ The difference between numbers of fecal bacteria determined by the MPN method and by culture-independent methods (FBA and FISH) in highly contaminated canal samples was relatively smaller compared to river samples. Thus the difference might be affected by physiological state of resident bacteria.

The high abundance of $E$. coli determined by both culture-dependent and -independent methods indicated that the waters of some canals are grossly contaminated by fecal flora, which might constitute a considerable cell fraction. The U.S. Environmental Protection Agency (USEPA) has suggested an ambient water quality goal for E. coli of $126 \mathrm{CFU}$ $100 \mathrm{ml}^{-1}$ in freshwater environments. ${ }^{22)}$ We cannot reasonably conclude that the $E$. coli detected by our techniques corresponds to a fecal source of pollution in the canals, but the high abundance of anaerobic Bacteroides does support this notion because these microbes cannot survive for long in the presence of dissolved oxygen. ${ }^{20)}$
Rivers and canals are important sources of fresh water, and outbreaks of infectious disease from unsafe water represent primary threats. ${ }^{24,25)}$ The present study is the first step towards assessing microbial quality in tropical fresh waters. Some researchers have isolated bacteriophages specific for pathogenic bacteria such as E. coli O157 : H7, Salmonella typhimurium and Bacteroides fragilis. ${ }^{6}$ We believe that FBA can rapidly and sensitively detect viable pathogenic bacteria, and thus should be a valuable tool with which to assess threats to public health from contaminated waters.

Acknowledgements We thank Mr. Naohiro Noda for providing the fluorescent bacteriophage. This study was supported by the JSPS Grant-in-Aid for Scientific Research (A) (17256001) and JSPS Grantin-Aid for Scientific Research (B) (11691152).

\section{REFERENCES}

1) Amann, R. I., Ludwig, W. and Schleifer, K. H. (1995) Phylogenetic identification and in situ detection of individual microbial cells without cultivation. Microbiol. Rev., 59, 143-169.

2) Glöckner, F. O., Amann, R., Alfreider, A., Pernthaler, J., Psenner, R., Trebesius, K. H. and Schleifer, K. H. (1996) An in situ hybridization protocol for detection and identification of planktonic bacteria. Syst. Appl. Microbiol., 19, 403-406.

3) Kenzaka, T., Yamaguchi, N., Tani, K. and Nasu, M. (1998) rRNA-targeted fluorescent in situ hybridization analysis of bacterial community structure in river water. Microbiology (Reading, U. K.), 144, 2085-2093.

4) Hennes, K. P., Suttle, C. A. and Chan, A. M. (1995) Fluorescently labeled virus probes show that natural virus populations can control the structure of marine microbial communities. Appl. Environ. Microbiol., 61, 3623-3627.

5) Noble, R. T. and Fuhrman, J. A. (2000) Rapid virus production and removal as measured with fluorescently labeled viruses as tracers. Appl. Environ. Microbiol., 66, 3790-3797.

6) Leclerc, H., Edberg, S., Pierzo, V. and Delattre, J. M. (2000) Bacteriophages as indicators of enteric viruses and public health risk in groundwaters. $J$. Appl. Microbiol., 88, 5-21.

7) Goodridge, L., Chen, J. and Griffiths, M. (1999) Development and characterization of a fluorescent-bacteriophage assay for detection of Escherichia coli O157:H7. Appl. Environ. Microbiol., 65, 1397-1404. 
8) Goodridge, L., Chen, J. and Griffiths, M. (1999) The use of a fluorescent bacteriophage assay for detection of Escherichia coli $\mathrm{O} 157: \mathrm{H} 7$ in inoculated ground beef and raw milk. Int. J. Food Microbiol., 47, 43-50.

9) Yokomaku, D., Yamaguchi, N. and Nasu, M. (2000). Improved direct viable count procedure for quantitative estimation of bacterial viability in freshwater environments. Appl. Environ. Microbiol., 66, 5544 5548.

10) Reasoner, D. J. and Gerldreich, E. F. (1985) A new medium for the enumeration and subculture of bacteria from potable water. Appl. Environ. Microbiol., 49, 1-7.

11) Hurst, C. J., Knudsen, G. R., McInerney, M. J., Stetzenbach, L. D. and Walter, M. V. (1997) Manual of environmental microbiology, American Society for Microbiology, Washington, D.C., pp. 187-189.

12) Muniesa, M. and Jofre, J. (1998) Abundance in sewage of bacteriophages that infect Escherichia coli O157:H7 and that carry the Shiga toxin 2 gene. Appl. Environ. Microbiol., 64, 2443-2448.

13) Amann, R. I., Binder, B. J., Olson, R. J., Chisholm, S. W., Devereux, R. and Stahl, D. A. (1990) Combination of $16 \mathrm{~S}$ rRNA-targeted oligonucleotide probes with flow cytometry for analyzing mixed microbial populations. Appl. Environ. Microbiol., 56, 19191925.

14) Manz, W., Amann, R., Ludwing, W., Vancanneyt, M. and Schleifer, K. H. (1996) Application of a suite 16S rRNA-specific oligonucleotide probes designed to investigate bacteria of the phylum CytophagaFlavobacter-Bacteroides in the natural environment. Microbiology (Reading, U. K.), 142, 1097-1106.

15) Kenzaka, T., Yamaguchi, N., Prapagdee, B., Mikami, E. and Nasu, M. (2001) Bacterial community composition and activity in urban rivers in Thailand and Malaysia. J. Health Sci., 47, 353-361.

16) Wallner, G., Amann, R. and Beisker, W. (1993) Optimizing fluorescent in situ hybridization with rRNA-targeted oligonucleotide probes for flow cytometric identification of microorganisms.
Cytometry, 14, 136-143.

17) Yamaguchi, N., Kenzaka, T. and Nasu, M. (1997) Rapid in situ enumeration of physiologically active bacteria in river waters using fluorescent probes. Microb. Environ., 12, 1-8.

18) Jones, J. G. (1977) The effect of environmental factors on estimated viable and total populations of planktonic bacteria in lakes and experimental enclosures. Freshwater Biology, 7, 67-91.

19) Staley, J. T. and Konopka, A. (1985) Measurement of in situ activities of nonphotosynthetic microorganisms in aquatic and terrestrial habitats. Ann. Rev. Microbiol., 39, 321-346.

20) Fiksdal, L., Maki, J. S., LaCroix, S. J. and Staley, J. T. (1985) Survival and detection of Bacteroides spp., prospective indicator bacteria. Appl. Environ. Microbiol., 49, 148-150.

21) Holdeman, L. V., Good, I. J. and Moore, W. E. (1976) Human fecal flora: variation in bacterial composition within individuals and a possible effect of emotional stress. Appl. Environ. Microbiol., 31, 359-375.

22) Dufour, A. P., Ericksen, T. H., Ballentine, R. K., Cabelli, V. J., Goldberg, M. and Fox, W. E. (1986) Bacteriological ambient water quality criteria for marine and fresh recreational waters. In Ambient water quality criteria for bacteria, EPA/440/5-84/002, U.S. Environmental Protection Agency, Washington, D.C.

23) Carrillo, M., Estrada, E. and Hazen, T. C. (1985) Survival and enumeration of the fecal indicators Bifidobacterium adolescentis and Escherichia coli in a tropical rain forest watershed. Appl. Environ. Microbiol., 50, 468-476.

24) Tillett, H. E., de Louvois, J. and Wall, P. G. (1998) Surveillance of outbreaks of waterborne infectious disease: categorizing levels of evidence. Epidemiol. Infect., 120, 37-42.

25) Barrell, R. A., Hunter, P. R. and Nichols, G. (2000) Microbiological standards for water and their relationship to health risk. Commun. Dis. Public Health, 3, 8-13. 